\title{
Kebijakan Online Single Submission sebagai E- Government dalam Mewujudkan Good Governance di Indonesia
}

\author{
Rahmi Ayunda ${ }^{1^{*}}$, Nertivia ${ }^{2}$, Laode Agung Prastio ${ }^{3}$, Octa Vila ${ }^{4}$ \\ ${ }^{1-4}$ Fakultas Hukum, Universitas Internasional Batam, Indonesia \\ Corresponding email: rahmi@uib.ac.id
}

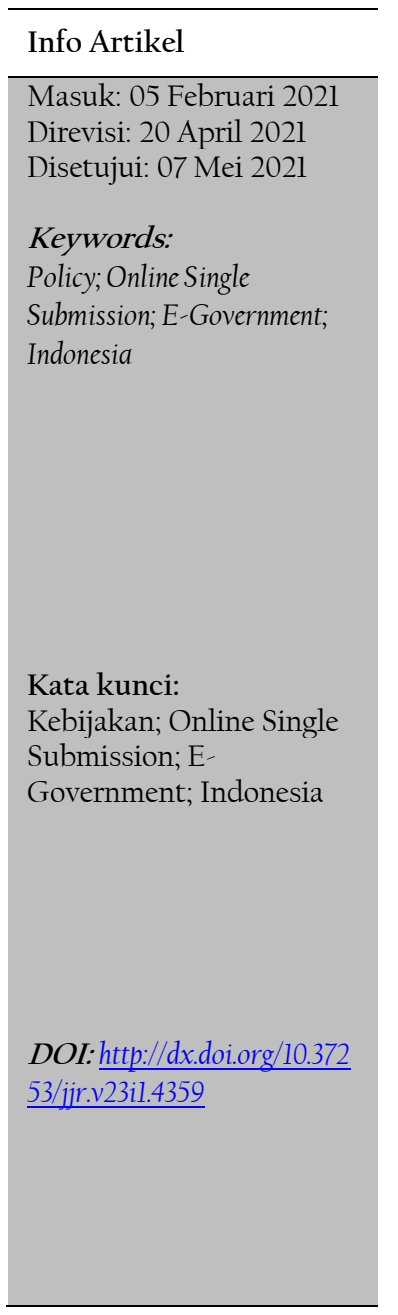

\begin{abstract}
Based on the history before the reform era, there have been many cases of government committing corruption, collusion and nepotism, this is the background of the movement to create a government to run good governance. As time has progressed, the time has come for a time that is all full of digitalization, both in the economy, education and politics. This research uses normative legal research methods. This study shows that the government in running its government will also be based on the development of sophisticated information technology which can be called E-Government. Therefore, there is now a time when the Indonesian government has used and allowed the Online Single Submission (OSS) system to make it easier for people who want to take care of business licensing. The implementation of good governance during the Industry 4.0 Revolution can take advantage of science, technology and information to provide good facilities and services to the Indonesian people, and the public can easily access government information.
\end{abstract}

\section{Abstrak}

Berdasarkan sejarah sebelum masa reformasi, telah banyak terjadi kasus pemerintah yang melakukan Korupsi Kolusi dan Nepotisme, hal demikian merupakan latar belakang adanya gerakan untuk menciptakan pemerintah menjalankan pemerintah yang baik (good governance). Seiring berkembangnya waktu, tibalah saatnya di masa yang serba dengan digitalisasi, baik dalam perekonomian, pendidikan maupun politik. Penelitian ini menggunakan metode penelitian hukum normatif. Penelitian ini menunjukan bahwa pemerintah dalam menjalankan pemerintahannya juga akan berdasarkan perkembangan informasi teknologi yang canggih yang bisa disebut dengan E-Government. Oleh karena itu ada masa sekarang ini, Pemerintah Indonesia telah mempergunakan dan mengizinkan sistem Online Single Submission (OSS) untuk memudahkan masyarakat yang ingin mengurus perizinan usaha. Penerapan good governance dalam masa Revolusi Industry 4.0 dapat memanfaatkan ilmu, teknologi dan informasi memberikan fasilitas dan pelayanan yang baik kepada masyarakat Indonesia, serta masyarakat juga dapat mudah dalam mengakses informasi pemerintahan. 


\section{A. PENDAHULUAN}

Menjalankan sistem pemerintahan negara Indonesia, masyarakat mengharapkan pemerintah dapat menciptakan "good governance" atau penyelenggaraan pemerintahan yang baik. Mengingat sejarah Indonesia pada masa sebelum reformasi, bahwa terjadinya kasus krisis di Indonesia seperti krisis ekonomi. Dimana dalam masa itu, penyelenggaran pemerintah tidak dikelola dengan baik dan efektif, banyaknya terjadi kasus "Korupsi, Kolusi dan Nepotisme atau KKN" yang dilakukan oleh pejabat publik negara. Pada saat itu juga, kasus KKN sulit diatasi dan diselesaikan. Sehingga hal tersebut jelas menghambat dan membuat perekonomian Indonesia menjadi rusak (Nasrullah, 2017; Kurnia, Rauta $\&$ Siswanto, 2017). Perlahan-lahan sistem penyelenggaraan pemerintah menjadi membaik karena disebabkan oleh adanya demokrasi. Demokrasi dapat diartikan sebagai pemerintahan dari rakyat, oleh rakyat dan untuk rakyat. Keikut sertaan masyarakat Indonesia dalam sistem pemerintahan menjadi semakin erat dan kuat (Robby \& Tarwini, 2019).

Seiring berjalannya waktu, pengembangan ilmu, teknologi dan informasi menjadi begitu pesat. Dimana sekarang kita hidup di masa Revolusi 4.0. Fenomena-fenomena yang terjadi dalam Era Revolusi 4.0 ini sudah menjadi tidak asing. Pada masa ini dimana banyak perusahaan-perusahaan Indonesia yang pabriknya menerapkan sistem koneksi internet yang bertujuan agar memudahkan pekerjaan internal maupun eksternal karyawan. Sangat jelas dapat dibuktikan bahwa perlahan-lahan semua kegiatan sudah mulai beralih menjadi digital, sehingga interaksi antar manusia dapat dikatakan berubah menjadi interaksi antara manusia dengan teknologi (Wirawan, 2020). Hal tersebut tentu saja tidak hanya berdampak bagi perusahaan perindustrian, namun berdampak bagi negara dalam menjalankan pemerintaha. Ketika dunia fisik, digital, dan biologis terus menyatu, teknologi dan platform baru akan semakin memungkinkan warga negara untuk terlibat dalam pemerintahan, menyuarakan pendapat mereka, mengkoordinasikan upaya mereka, dan bahkan menghindari pengawasan otoritas public (Amalia, 2018).

Berdasarkan paparan di atas, penelitian ini akan mengkaji peran "Kebijakan Online Single Submission sebagai E-Government dalam Mewujudkan Good Governance di Indonesia". Rumusan masalah dalam penelitian ini mempertanyakan apakah yang dimaksud dengan good governanace dan bagaimana penerapan good governance di Indonesia; mempertanyakan bagaimana sistem pemerintahan pada masa Era Revolusi 4.0; dan bagaimana cara menerapkan good governanace di Era Revolusi 4.0 di Indonesia.

\section{B. METODE PENELITIAN}

Metode penelitian yang digunakan dalam penelitian ini adalah metode penelitian hukum normatif dengan menggunakan data sekunder atau data yang 
diperoleh secara tidak langsung. Pendekatan yang digunakan dalam penelitian hukum ini adalah pendekatan perundang-undangan dengan teknik analisis deskriptif kualitatif.

\section{HASIL DAN PEMBAHASAN}

\section{Penerapan Good Governance di Indonesia}

Seperti yang diketahui Negara Indonesia merupakan Negara kesatuan yang dimana Negara Indonesia ini menerapkan sistem good governance pada sistem pemerintahan (Irwan, 2008). Good governance disini adalah pelaksanaan pemerintah secara tertib, bersih, ramah dan tanpa cacat salah satunya harus mempunyai atau biasa disebut juga dengan pemerintahan yang baik atau lebih tepatnya good governance merupakan sebuah cara untuk memperkuat kerja Lembaga-lembaga dalam pemerintahan (Duadji, 2012; Arisaputra, 2013), sehingga dapat memperkuat aturan hukum mencegah adanya akar Korupsi, Kolusi dan Nepotisme (KKN) serta menjamin juga bahwa kinerja dalam institusi pemerintah dapat dikumpulkam dan juga dapat diberikan kepada masyarakat sehingga masyarakat bisa melihat dan memantau secara langsung terhadap manajemen pemerintah. Untuk mengwujudkan good governance ini wajib menjalankan asas umum pemerintahan ini secara aktif, baik digunakan sebagai hukum lisan dengan melalui pelaksanaan, penerapan dan pembentukan hukum (Martua, 2019; Arliman, 2019).

Pada umumnya terdapat juga prinsip dari good governance, yaitu: "1) Transparancy, dibentuknya asas ini atas dasar menjadi arus informasi dimana seluruh informasi tentang pemerintahan dari proses awal bisa di akses bebas oleh pihak yang berkepentingan dan informasi yang tersedia juga harus memenuhi syarat agar mudah untuk dimengerti oleh orang yang mengaksesnya; 2) "Peduli terhadap stakeholder", macam-macam bentuk lembaga dan seluruh proses pemerintahan yang berusaha melayani semua pihak yang memiliki kepentingan; 3) Orientasi terhadap consensus, pemetaan pemerintahan yang baik dalam menampung seluruh kepentingan masyarakat yang berbeda agar terbangunnya kesepakatan yang baik bagi para masyarakat; 4) Kesetaraan, setiap kelompok masyarakat masing-masing mempunyai hak untuk mempertahankan kesejahteraan mereka; 5) Efektifitas dan efisiensi, segala tahap pemerintahan dan Lembaga akan menghasilkan hasil yang bermanfaat terhadap masyarakat dengan menggunakan sumber daya semaksimal mungkin; 6) Akuntabilitas, Lembaga yang memutuskan keputusan dipemerintahan, sektor swasta dan juga dalam organisasi maupun masyarakat, bertanggung jawab atas masyarakat maupun Lembagalembaga yang berkepentingan; 7) Visi strategis, seorang pimpinan atau masyarakat yang memiliki pandangan yang luas atas pemetaan pemerintahan dan pembangunan, disertai dengan kepekaan untuk mengwujudkannya. harus memiliki kepahaman atas hal yang rumit sosial budaya yang menjadi dasar dari suatu pandangan tersebut; 8) Partisipasi masyarakat, setiap warga masyarakat 
mempunyai hak dalam memberikan suara dengan secara langsung maupun secara tidak langsung; dan 8) Tegaknya supremasi hukum, rancangan hukum harus bertindak adil dan diperlakukan tanpa memandang rendah, termasuk didalamnya hukum-hukum terkait dengan hak asasi manusia".

Seiring dengan berjalannya waktu pemerintahan yang baik maupun tidak baik itu termasuk dalam nilai etika. Oleh karena itu, asas-asas untuk melaksanakan nilai etika salam struktur ilmu pemerintahan berhak menjadi bagian nilai etika pemerintahan. Adapun asas-asas UU Administrasi Pemerintahan (UUAP) dapat dibagi menjadi 3 yaitu: "1) Asas Legalitas yang berarti dalam menjalankan sistem pemerintahan harus mengedepankan atau berdasarkan hukum yang berlaku. Pemerintah dalam menjalankan pemerintahannya harus bertindak sebagaimana merupakan wewenang dan tugas nya, tidak boleh bertindak sewenang-wenang; 2) Asas Perlindungan HAM berarti dalam menjalankan sistem pemerintahan harus mengedepankan hak asasi manusia, tidak boleh bertentangan serta melanggar hakhak asasi manusia (HAM) sebagaimana hak asasi manusia (HAM) telah diatur dalam "Pasal 28 Undang-undang Dasar Negara Republik Inonesia Tahun 1945" yang merupakan landasan konstitusi negara Indonesia, sehingga tidak boleh dilanggar; 3) Asas-asas Umum Pemerintahan yang Baik, yaitu dengan adanya asas kepastian hukum, kemanfaatan, keadilan. Dimana 3 asas ini juga merupakan cita hukum Indonesia. Hukum Indonesia yang dibuat harus memenuhi 3 unsur tersebut yaitu harus adanya kepastian hukum, kemanfaatan bagi orang yang menjalani dan keadilan tidak boleh berpihak kepada siapa pun. Selain itu juga terdapat asas kecermatan, keterbukaan, asas untuk kepentingan umum, pelayanan yang baik, tidak penyalahgunaan wewenang, dan kecermatan, serta asas-asas lainnya yang dijadikan sebagai dasar penilaian hakim dalam sebuah putusan pengadilan”. Namun terdapat juga asas-asas pemerintahan menurut beberapa ahli. Asas-asas tersebut silih berganti dari waktu ke waktu namun tujuannya sama, untuk menciptakan pemerintahan yang baik. Pada tahun 1952 di Nederland terdapat literature yang membahas tentang asas good governance dimana terdapat lima asas, yaitu "1) asas fair play, 2) asas kecermatan, 3) asas kemurnian arah tujuan, 4) asas keseimbangan, dan 5) asas kepastian hukum".

Akhir tahun 1978, ada beberapa asas yang dikembangkan lagi oleh "Crince-le Roy" dan "Koentjoro Poerbopranoto" menjadi, sebagai berikut "l) principle of legal security, 2) principle of proportionality, 2) principle of carefulness, 4) principle of motivation, 5) principle non misuse of competence, 6) principle equality, 7) principle of fair play, 8) principle of reasonableness or prohibition of arbiruriness, 9) principle of meeting raised expection, 10) principle of undoing the consequenceses of unmulled decision, 11) principle of protecting the personal way of live, 12) principle of sapiently, dan 13) principle of public service".

Menurut Syafrudinz ada beberapa asas yang harus diketahui oleh pemerintahan yang baik adalah. "l) Persamaan ialah dimana semua hal yang sama harus diperlakukan sejajar dan sama, disamping itu asas tersebut juga merupakan 
asas yang paling mendasar dalam lingkungan administrasi; 2) Kepercayaan, dimana dalam hukum asas ini dianut sebagai asas bahwa harapan akan timbul jika harapan tersebut dapat di penuhi; 3) Kepastian hukum merupakan di dalam suatu Negara sangat memerlukan asas ini serta mengutamakan perundang-undangan, keadilan dan kepatuhan terhadap setiap penyelenggara; 4) Kecermatan, mengandung arti dimana pada saat pemerintah mengambil sebuah keputusan bisa meneliti terlebih dahulu fakta yang sebenarnya dan memasukkan semua kepentingan kedalam pertimbangan tersebut; 5) Pemberian alasan, asas ini mengandung arti dimana setiap suatu ketatapan yang diberikan harus didasari dengan alasan-alasan; dan 6) Larangan penyalahgunaan wewenang, suatu kewenangan yang telah diberikan tidak bisa digunakan untuk tujuan lain selain dari hak wewenang yang telah diberikan".

Berdasarkan konstitusi negara Republik Indonesia yaitu "pasal 1 ayat 3, Undang-Undang Dasar Negara Indonesia tahun 1945" atau UUD NRI 1945, menyatakan bahwa "Negara Indonesia adalah Negara Hukum", maka jelas Indonesia adalah negara rechtsstaat bukan negara machtstaat atau negara berdasarkan kekuasaan. Maka dari itu dalam menjalankan sistem pemerintahan Indonesia, para pejabat harus bertindak dan melakukan tugas sebagaimana tertera dalam peraturan perundang-undangan. Dapat disimpulkan bahwa penerapan good governance di Indonesia memiliki kaitan yang erat dengan konstitusi negara kita UUD NRI 1945.

Tujuan kita menerapkan good governance tersebut agar bentuk penyelenggara manejemen pembangunan yang utuh dan bertanggung jawab agar bisa sejalan dengan pasar yang lebih menguntungkan, untuk menghindari salahnya penentuan dalam hal investasi dan juga penghindaran terhadap korupsi baik secara politik maupun administratif. Manfaat menuju good governance merupakan untuk kepentingan Negara dan pemerintahan dalam meningkatkan efisiensi produktivitas dalam penerapan penyelenggaraan good governance, sehingga pemerintah dapat meningkatkan kepercayaan terhadap masyarakat dan menjaga kelangsungan pemerintahan daerah untuk target kinerja pemerintah daerah tersebut.

Mengingat sejarah Indonesia pada masa sebelum reformasi, dimana banyaknya kasus korupsi, kolusi dan nepotisme (KKN), maka dengan diterapkannya good governance dengan tujuan sebagaimana sudah dijelaskan sebelumnya, bahwasannya dapat membawakan negara Indonesia menjadi negara yang lebih maju daripada yang sebelumnya dan juga memiliki potensi serta kualitas pemerintahan yang jauh lebih baik lagi. Hal ini jelas merupakan cita-cita negara Indonesia maupun masyarakat Indonesia, menwujudkan masyarakat dan negara yang sejahtera.

Penyalahgunaan suatu kewenangan juga bertentangan dnegan peraturan perundang-undangan. Tetapi pada umumnya di Indonesia terjadi banyak sekali 
kasus karena adanya penyalahgunaan wewenang yang kebanyakan kasus yang muncul berasal dari administrasi. Asas yang dijelaskan di atas merujuk kepada pemerintahan bagaimana mereka bisa mengoperasikan atau mengatur permerintahan dengan secara baik, patut, dan layak

Dalam mencegah penyelenggaraan pemerintahan dengan sewenang-wenang, terdapat pembagian kekuasaan, seperti lembaga legislatif, eksekutif dan yudikatif; "l) Lembaga Legislatif yaitu lembaga pembuat atau pembentuk peraturan perundang-undang seperti Dewan Perwakilan Rakyat, Dewan Perwakilan Daerah; 2) Lembagai Eksekutif yaitu lembaga yang menjalankan pemerintahan seperti Presiden dan atau Wakil presiden yang dibantu oleh menteri-menteri; 3) Lembaga Yudikatif yaitu lembaga yang menjalankan kekuasaan kehakiman, seperti Mahkamah Agung (MA), Mahkamah Konstitusi (KY), dan Komisi Yudisial (KY)". Meskipun terdapat pembagian kekuasaan, namun dalam menjalankan tugas dan wewenangnya juga memiliki kaitan yang erat antar satu lembaga dengan lembaga lainnya.

\section{Kajian Umum Era Revolusi 4.0}

Era Revolusi 4.0 merupakan penamaan masa atau era dimana pada zaman sekarang ini dalam menjalani kehidupan sehari-hari serba dengan teknologi tanpa memerlukan tenaga kerja manusia. Revolusi industri pada awalnya berasal dari ditemukannya mesin uap oleh James Watt pada abad ke-18. Kemudian dilanjutkan dengan ditemukannya listrik sehingga dalam proses produksi barang jauh lebih mudah dibanding masa sebelumnya. Seiring berkembangnya waktu, mindset manusia berubah menjadi lebih kreatif, perlahan-lahan muncullah komputer dan robot agar dalam proses pembuatan suatu barang tidak memerlukan waktu yang lama dan lebih efisien.

Dengan seiring perkembangan dan kemajuan teknologi dari waktu ke waktu, maka dalam revolusi 3.0 cikal bakal perubahan dari analog menjadi digital tertampak jelas. Hingga saat ini memasuki era revolusi 4.0 dengan adanya interkoneksi yang mempermudah interaksi manusia antar satu sama lain, menghubungkan manusia, dan mesin. Terdapat juga transparansi informasi yang memudahkan manusia dalam mengidentifikasi dan mengumpulkan data-data bantuan teknis dan lain sebagainya. Dengan perkembangan teknologi, informasi tidak hanya berdampak pada manufaktur perekonomian, namun juga berpengaruh terhadap pendataan dalam sistem pemerintahan.

\section{Sistem Online Dalam Pengurusan Administrasi}

Dua (2) tahun belakangan ini, terdapat banyak perubahan dalam segi administrasi seperti terjadinya prosedur dan syarat pendirian PT (Perseroan Terbatas) yang mengalami perubahan terutama dalam hal pengurusan usahanya. Perubahan tersebut dapat dilihat pada saat berlakunya sistem Online Single 
Submission (OSS) sebagai prosedur dan syarat pendirian PT di tahun 2018. Online Single Submission (OSS) adalah singkatan dari online single submission (Assegaf, Juliani \& Sa'adah, 2019). OSS merupakan salah satu bentuk perizinan untuk melakukan usaha yang diterbitkan oleh lembaga Online Single Submission (OSS) yang berwewenang". Izin ini disetujui oleh pemerintah seperti Mentri, Gubernur, Walikota /Bupati atau piminan lembaga. Bentuk izin ini diberikan kepada setiap pelaku usaha dengan menggunakan sisten integrasi secara elektronik. Dimana para pelaku usaha diharuskan untuk memiliki NIB dengan cara mendaftarkan pelaku usaha melalui Online Single Submission (OSS) Republik Indonesia dan saat mengurusnya tidak dikenakan biaya (Atmanto, 2020).

Diberlakuan Online Single Submission (OSS) merupakan amanat dari "Peraturan Presiden (Perpres) No 91 tahun 2017 tentang Percepatan Pelaksanaan Pelaku Usaha." Dalam Peraturan Presiden (PERPRES) RI No. 91 Tahun 2017 tentang percepatan pelaksanaan berusaha dalam isinya menuangkan pertimbangan tentang perlu diterbitkan percepatan pelaksaan berusaha yaitu: "1) Dalam pertambahan dan perkembangan jumlah, penyebaran, skala, maupun efisiensi kegiatan usaha merupakan penentu utama petumbuhan ekonomi, penciptaan lapangan kerja, pengurangan kemiskinan serta ketimpangan anatar daerah maupun antara kelompok pendapatan”; "2) Bahwasannya izinan dalam berusaha bisa diterbitkan kemetrian/ lembaga dan pemerintahan daerah dalam melalui, melaksanakan, dan mengembangkan pelaku kegiatan usaha, perlu untuk disusun kembali untuk menjadi pendukung dan melainkan bukan sebagai menjadi sebuah hambatan dalam perkembangan kegiatan usaha yang ada di masyarakat Indonesia”; “3) Bahwasannya dalam melakukan susunan kembali sebagimana yang diterangkan dalam huruf b yang diwujudkan dalam sebuah bentuk pelayanan, pengawalan, dan sebuah peran aktif dalam menyelesaikan hambatan dalam pelaksaan berusaha yang diawali dari pembentukan satuan tugas pada tingkat nasional, kementrian/ lembaga, daerah provinsi dan derah kabupaten/kota”; “4) Untuk mempercepat pelaksaan usaha di daerah kawasan ekonomi khusus, daerah perdagangan bebas dan pelabuhan bebas, kawasan industry, dan atau kawasan pariwisata sudah dapat dilakukan dalam bentuk persyaratan (checklist)"; "5) Dalam menyederhanakan izin pelaku usaha lebih lanjut harus diatur serta ditetapkan kembali standar pelayanannya pada kementrian/lembaga, daerah provinsi dan daerah kabupaten/kota, dengan menggunakan reformasi peraturan untuk melaksanakan kegiatan usaha"; "6) Untuk mempercepat serta mempermudah pelayanan dalam berusaha harus mengimplementasi penggunaan teknologi dan informasi melalui sistem perizinan berusaha terintergriras dengan adanya elektronik (Online Single Submission)"; dan "7) Dengan pertimbangan sebagaimana dalam huruf A-F harus ditetapkan dengan adanya peraturan presiden tentang percepatan pelaksaaan berusaha". 
Secara yuridis, adapun dasar hukum penyelenggaraan Online Single Submission (OSS) adalah: "1) Konstitusi Negara, Pasal 4 ayat (1) UUD NRI 1945"; “2) Undang - Undang Nomor 36 Tahun 2000 Tentang Penetapan Peraturan Pemerintah Penganti Undang - Undang Nomor 1 Tahaun 2000 Tentang Kawasan Perdagangan Bebas Menjadi Undang - Undang sebagaimana telah diubah dengan Undang - Undang Nomor 1 Tahun 2007 Tentang Perubahan Atas Undang Undang Nomor 36 Tahun 2000 Tentang Penetapan Peraturan Pemerintah Pengganti Undang - Undang Nomor 1 Tahun 2000 Tentang Kawasan Perdagangan Bebas Dan Pelabuhan Bebas Menjadi Undang - Undang Menjadi Undang Undang”; 3) "Undang - Undang Nomor 25 tahun 2007 tentang Penanaman Modal”; "4) Undang - Undang nomor 10 tahun 2009 tentang”; "5) Undang - Undang nomor 39 tahun 2009 tentang Kawasan Ekonomi Khusus”; “6) Undang - Undang nomor 3 tahun 2014 tentang Perindustrian"; dan "7) Undang - Undang Nomor 23 tahun 2014 tentang Pemerintahan Daerah sebagaimana telah beberapa kali diubah, terakhir dengan Undang - Undang Nomor 9 tahun 2015 tentang Perubahan Kedua Atas Undang - Undang Nomor 23 Tahun 2014 tentang Pemerintahan Daerah”.

Ketentuan umum dalam Peraturan Presiden (PERPRES) No 91 tahun 2017 tentang Percepatan Pelaksaaan Berusaha, menegaskan: "1) Satuan tugas merupakan lembaga yang dibentuk dalam tujuan peningkatan pelayanan, pengawalan serta penyelesaian segala hambatan yang terjadi dan mengembangkan sistem online dalam proses perizinan berusaha baik dalam usaha makro, mikro maupun menengah"; "2) Perizinan berusaha merupakan suatu tindakan sebelum mendirikan dan memulai usaha, dengan perlunya persetujuan terlebih dahulu yang dituangkan atau dibuat dalam surat atau keputusan (checklist)"; "3) Pemerintahan pusat adalah Lembaga pemerintahan yang tertinggi seperi Presiden Republik Indonesia, dimana presiden memegang kekuasaan pemeritahan Negara Republik Indonesia yang dibantu oleh wakil presiden dan mentri sebagimana dimaksud dalam UUD NRI 1945”; “4) Kepustusan elektronik merupakan suatu keputusan yang dikeluarkan dalam bentuk atau yang disampaikan dengan menggunakan media elektronik"; “5) Pelaku usaha merupakan subyek hukum (nartulick person) perseorangan atau badan usaha yang ingin memulai kegiatan usahanya dengan mengajukan permohonan penerbitan perizinan"; "6) Standar pelayanan adalah sebuah tolok ukur yang dipergunakan sebagimana pedoman penyelengaraan pelayanan oleh pemerintah yang memuat ketentuan mengenai pelaku usaha yang berhak, persyaratan, prosedur penyelesaian, dan jangka waktu penyelesain"; "7) KEK (Kawasan ekonomi khusus yang selanjutnya disingkat) adalah kawasan dengan batas tertentu dalam wailayah hukum Negara kesatuan republic indonesia yang ditetapkan untuk menyelanggarakan fungsi perekonomian dan memperoleh fasilitas tertentu"; "8) KPBPB (Kawasan perdagangan bebas) merupakan sebuah kawasan yang dimana berada dalam sebuah wilayah hukum Negara kesatuan Republik Indonesia yang terpisah dari daerah pabean sehingga bebas dari bea 
masuk, pajak pertambahan nilai, pajak penjualan atas barang, mewah dan cukai"; “8) Kawasan industria adalah sebuah wilayah yang diperuntukan untuk menunjang kegiatan usaha yang difasilitasi dengan segala sarana prasana untuk memproduksi suatu produk yang dikelola oleh perusahaan Kawasan industry"; "9) Kawasan strategi pariwisata adalaha kawasan nasional yang selanjutnya dapat disingkat KSPN adalah kawasan startegi pariwisata sebagaimana dimaksud dalam Undang - Undang Nomor 10 Tahun 2009 tentang Kepariwisataan”; “10) PTSP (Pelayanan terpadu satu pintu) adalah pelayanan secara singkat terintegritas dalam satu kesatuan proses dimulai dari tahap permohonan sampai dengan tahap penyelesaian produk pelayanan melalui satu pintu"; "ll) PTSP Pusat adalah pelayanan terkait penanaman modal yang dimana merupakan kewenangan pemerintah pusat yang di selenggarakan secara terintegritas dalam sebuah satu kesatuan proses dimulai dari tahap permohonan sempai dengan tahap penyelesaian produk pelayanan melalui satu pintu di badan koordinasi penanaman modal"; "12) PTSP KEK adalah PTSP yang dimana dielenggarakan oeleh administrasi KEK"; "13) Dinas penananaman Modal dan Pelayanan Terpadu Satu Pintu Propinsi yang selanjutnya disingkat DPMPTSP provinsi adalah penyelenggaraan PTSP di provinsi"; dan "14) "Dinas Penanaman Modal dan Pelayanan Terpadu Satu Pintu Kabupaten/ Kota yang selanjutnya dapat disingkat oleh DPMPTSP Kabupaten/koata adalah penyelenggaraan PTSP kabupaten/kota”.

Dalam diberlakukannya Online Single Submission (OSS) ini diharapkan juga memberikan manfaat bagi para pelaku usaha dalam menerbitkan usahanya berikut merupakan manfaat yang ditimbukan dalam pembentukan Online Single Submission (OSS) yaitu :

Pertama, Mempermudah berbagai perizinan. Manfaat Online Single Submission (OSS) yang pertama adalah mempermudah perizinan. Hal tersebuat mencakup prasyarat untuk melakukan usaha, seperti izin mengenai lokasi, lingkungan dan juga bangunan. Oss juga bermanfaat agar mendapatkan berbagai izin yang diperlukan dalam tingkat pusat maupun daerah (Assegaf, Juliani $\&$ Sa'adah, 2019).

Kedua, Memberikan fasilitas untuk pelaku usaha untuk para pelaku bisnis. Dengan adanya Online Single Submission (OSS), semua pemangku kepentingan atau stakeholder,Biasa Mendapatkan Fasilitas Untuk Usaha mereka. Tujuannya agar para pelaku usaha bias mendapatkan izin secara cepat, aman dan juga real time. Online Single Submission (OSS) juga dapat diandalkan karena bias memfasilitasi para pelaku usaha untuk memecahkan berbagai masalah perizinan dan melaporkannya. Pemilik usaha juga diberikan kebebasan untuk meyimpan data perizinan (Inggarwati, Celia \& Arthanti, 2020). Di negara Indonesia ini perizinan merupakan sebuah persoalan dalam menerbitkannya dikarenakan perizinan ini dapat di perjual belikan. 


\section{Penerapan Good Governance di Era Revolusi Industri 4.0 sebagai E- Government}

Disebabkan tuntutan-tuntutan yang melatar belakangi penerapan good governance yang bisa juga disebut dengan pemerintahan yang baik di Indonesia seperti terjadinya krisis ekonomi, politik, moneter, fiscal, dsb yang disebabkan karena tindakan "Korupsi, Kolusi dan Nepotisme (KKN)" oleh pemerintah. Dan juga seiring berkembangnya zaman dari zaman sebelum mengenalnya alat-alat canggih sampai saat ini semua hal yang dilakukan dan digunakan serba menggunakan digital jarang lagi menggunakan tenaga kerja manusia. Maka dalam penyelenggaraan pemerintahan juga demikian, bisa kita lihat bahwa perusahaan dalam mendirikan usahanya sistem perizinan yang dilakukan dapat berbasis online, sesuai dengan era globalisasi saat ini (Radiansyah, 2020). Namun hal demikian perlu kita garis bawahi dan waspadai. Tidak boleh lagi memicu timbulnya krisis multidimensional di negara tercinta Indonesia ini yang kelak akan menyebabkan kesusahan rakyat dan non kesejahteraan masyarakat Indonesia (Azhar, 2020).

Good governance (tata kelola pemerintahan yang baik) dengan menwujudkan pemerintahan yang bersih (clean governance) serta bebas Korupsi, Kolusi, Nepotisme (KKN) dengan prinsip transparansi, akuntabilitas serta menjunjung tinggi hukum sebab negara Indonesia adalah negara hukum, serta membuka pintu untuk rakyat berikut serta dalam sistem pemerintahan karena sebagaimana yang dimaksud dengan demokrasi (oleh rakyat, dari rakyat dan untuk rakyat) (Larasati, 2019).

Bahwa E-government adalah tata cara pemerintah dalam menjalankan pemerintahannya dengan memanfaatkan ilmu, teknologi dan informasi yang canggih pada masa ini seperti alat digital, web, internet, telekomunikasi dan lainlainnya untuk menyongkong, melayani, memfasilitasi masyarakat. Pada dasarnya untuk menciptakan pemerintahan yang baik (Good Governance) hal utama yang harus ditingkatkan adalah pelayanan publik kepada masyarakat. Dimana pelayanan ini dapat menggambarkan interaksi pemerintah dengan masyarakat. Pemerintah harus memberikan pelayanan kepada masyarakat secara adil dan merata tanpa membedea-bedakan strata sosial masyarakat. Pemerintah harus memberikan ruang kepada masyarakat agar inspirasi dari masyarakat terdengar oleh aparat pemerintah publik. Dengan adanya perkembangan ilmu, teknologi dan informasi ini, berharap pemerintah dapat memanfaatkan perkembangan tersebut meningkatkan kualitas pelayanan publik. Pemanfaatan teknologi canggih dapat dilakukan melalui 2 cara yaitu (Elysia \& Wihadanto, 2017): 1) Pemanfaatan perkembangan dan kemajuan teknologi agar masyarakat mudah mengakses pelayanan publik yang dipersiapkan oleh pemerintah; 2) Pengolahan data, pengelolaan sistem informasi dan proses kerja yang elektronis. Dalam Era Revolusi 4.0, pemerintah dalam mencegah terjadinya pelaksanaan tugas dan wewenang semena-mena, Kementerian Pendayagunaan Aparatur Negara dan Reformasi 
Birokrasi (MenpanRB) meluncurkan suatu aplikasi yang dapat diakses melalui http://sipp.menpan.go.id. Tujuannya sebagai tempat atau wadah informasi dan penyelenggaraan pelayanan publik secara nasional. Dengan adanya aplikasi ini, maka masyarakat dapat ikut serta berpartisipasi secara efektif .

\section{KESIMPULAN}

Menerapkan sistem pemerintahan yang baik (good governance) diperlukan keterlibatan antara masyarakat dan pemerintah. Dapat dikatakan juga bahwa harus menuntut keterlibatan semua komponen negara agar dapat memberikan pelayanan yang baik sesuai dengan ideologi negara dan landasan konstitusi negara. Prinsip - prinsip dari pemerintahan yang baik (good governance) yaitu Transparansi, Peduli terhadap stakeholder, Berorientasi pada consensus, Kesetaraan, Efektifitas dan efisiensi, Akuntabilitas, Visi strategis, Partisipasi masyarakat dan Tegaknya supremasi hukum. Tujuan dari penerapan good governance ini agar mencegah terjadinya penyelewengan tugas dan wewenang pemerintah Indonesia, dan juga mengawasi pelaksanaan pemerintah Indonesia serta memberikan ruangs untuk masyarakat dapat aktif berpartisipasi, sebagaimana sesuai dengan maksud demokrasi yaitu pemerintahan dari rakyat, oleh rakyat dan untuk rakyat. Dalam era revolusi industri 4.0, dimana pasa masa ini semua aspek kehidupan serba dengan digitalisasi. Setiap perusahaan di Indonesia menerapkan sistem internelisasi, dalam beberapa tahun ini, banyaknya perusahaan yang mendirikan usaha dan mengurus proses perizinan bersistem online. Pemerintah Indonesia telah mengizinkan sistem Online Single Submission (OSS) untuk memudahkan masyarakat yang ingin mengurus perizinan usaha. Dasar hukum OSS terdapat pada Peraturan Presiden (PERPRES) Nomor 91 tahun 2017 tentang Percepatan Pelaksanaan Pelaku Usaha.

Penerapan good governance dalam masa Revolusi Industri 4.0 dapat memanfaatkan ilmu, teknologi dan informasi memberikan fasilitas dan pelayanan yang baik kepada masyarakat Indonesia, serta masyarakat juga dapat mudah dalam mengakses informasi pemerintahan. Dengan dibentukannya OSS ini diharapkan dapat membantu para pelaku usaha dalam memperoleh perizinan untuk berusaha dan dapat mengurangi pungutan liar (pungli) atau pun tindakan korupsi yang dapat terjadi dikerenakan untu mempermudah mendapatkan izin usahanya.

\section{E. DAFTAR PUSTAKA}

Amalia, S. (2018). Reformasi Birokrasi 4.0: Strategi Menghadapi Revolusi Industri 4.0. Jurnal Wacana Kinerja: Kajian Praktis-Akademis Kinerja dan Administrasi Pelayanan Publik, 21(2).

Arisaputra, M. I. (2013). Penerapan Prinsip-Prinsip Good Governance Dalam Penyelenggaraan Reforma Agraria Di Indonesia. Yuridika, 28(2).

Arliman, L. (2019). Partisipasi masyarakat di dalam pengelolaan uang desa pasca 
undang-undang nomor 6 tahun 2014 tentang desa. Arena Hukum, 12(2), 296317.

Assegaf, M. I. F., Juliani, H., \& Sa'adah, N. (2019). Pelaksanaan Online Single Submission (OSS) dalam Rangka Percepatan Perizinan Berusaha di Dinas Penanaman Modal dan Pelayanan TERPADU Satu Pintu (DPMPTSP) Jawa Tengah. Diponegoro Law Journal, 8(2), 1328-1342.

Atmanto, P. D. (2020). The Online Single Submission Policy Of The Local Government Aparature In The Era Of Globalization. Jurnal Pembaharuan Hukum, 6(2).

Azhar, M. (2020). Government Strategy in Implementing the Good Governance during COVID-19 Pandemic in Indonesia. Administrative Law \& Governance Journal, 3(2), 300-313.

Duadji, N. (2012). Good Governance dalam Pemerintah Daerah. MIMBAR: Jurnal Sosial dan Pembangunan, 28(2), 201-209.

Inggarwati, M. P., Celia, O., \& Arthanti, B. D. (2020). Online Single Submission For Cyber Defense and Security in Indonesia. Lex Scientia Law Review, 4(1), 83-95.

Irwan, A. L. (2008). Pelaksanaan Otonomi Daerah dalam Mendukung Pelaksanaan Good Governance di Indonesia. Jurnal Administrasi dan Kebijakan Kesehatan Indonesia, 1(1), 89-98.

Kurnia, T. S., Rauta, U., \& Siswanto, A. (2017). E-Government dalam Penyelenggaraan Pemerintahan Daerah di Indonesia. Masalah-Masalah Hukum, 46(2), 170-181.

Larasati, D. C. (2019). Analisis Elemen Sukses E-Government Dalam Implementasi Sistem Informasi Aplikasi Mobile Pajak Daerah (Sampade) Kota Malang. In Conference on Innovation and Application of Science and Technology (CIASTECH) 2(1), 93-100.

Martua, J. (2019). Good Governance Dalam Penyelenggaraan Pemerintah Daerah. Citra Justicia: Majalah Hukum dan Dinamika Kemasyarakatan, 20(2), 3440.

Nasrullah, N. (2017). Implementasi Electronic Government Dalam Mewujudkan Good Governance dan Smart City (Studi Kasus: Pemerintah Kota Makassar). E-JURNAL JUSITI: Jurnal Sistem Informasi dan Teknologi Informasi, 6(2), 23-31.

Radiansyah, R. R. (2020). Reformasi Birokrasi Sebagai Upaya Mewujudkan Good Governance Melalui Kerangka Otonomi Daerah. Jurnal Inovasi Ilmu Sosial dan Politik (JISoP), 2(1), 80-93.

Robby, U. B. I., \& Tarwini, W. (2019). Inovasi Pelayanan Perizinan Melalui Online Single Submission (OSS) Studi Pada Izin Usaha di Dinas Penanaman Modal dan Pelayanan Terpadu Satu Pintu (DPMPTSP) Kabupaten Bekasi. Administratio: Jurnal Ilmiah Administrasi Publik dan Pembangunan, 10(2), 5157.

Wirawan, V. (2020). Penerapan E-Government dalam Menyongsong Era Revolusi Industri 4.0 Kontemporer di Indonesia. Jurnal Penegakan Hukum dan Keadilan, 1(1), 1-16.

Elysia, V., \& Wihadanto, A. (2017). Sumartono,"Implementasi e-government untuk 
mendorong pelayanan publik yang terintegrasi di Indonesia,". Optim. Peran Sains Dan Teknol. Untuk Mewujudkan Smart City, 353-380. 
This page intentionally left blank 